\title{
Managing Economic Recession through Effective Tax Collection: The Nigerian Experience
}

\author{
D. O. Gbegi ${ }^{1}$, J. F. Adebisi ${ }^{2} \&$ Bodunde Tosin ${ }^{3}$ \\ ${ }^{1}$ Department of Accounting Finance, University of Agriculture, Makurdi, Nigeria \\ ${ }^{2}$ Director General, Nigerian College of Accountancy, Kwall, Jos, Plateau State, Nigeria \\ ${ }^{3}$ Department of Accounting, University of Jos, Jos, Nigeria \\ Correspondence: D. O. Gbegi, Department of Accounting Finance, University of Agriculture, Makurdi, Nigeria.
}

Received: December 9, 2017

Accepted: December 27, 2017 Online Published: December 31, 2017

doi:10.20849/iref.v1i1.274

URL: https://doi.org/10.20849/iref.v1i1.274

\begin{abstract}
Economic recession has eaten deep into the economy to the extent that taxes generated cannot serve as a pivot upon which the economy could strive. This study examines how economic recession can be managed through effective tax collection. Secondary data was obtained from the CBN statistical bulletin between periods of 2003 to 2016. Regression technique was used in testing the data collected with the aid of E-VIEWS. The study revealed that taxes do not have significant positive effect on the nation's Gross Domestic Product, Government Spending, Capacity Utilization and Money Supply. Thus, it implies that taxes in Nigeria are rather unfortunately underexploited, which is an indication of poor tax collection system. This study therefore concludes that, tax should be considered as the urgent and needful panacea to rescue the current economic illness that Nigeria is currently facing. This should be done by ensuring that relevant tax authorities have good tax collection system like effective tax data base, effective E-tax registration, effective E-tax payment and all tax payers should have tax identification number.
\end{abstract}

Keywords: tax collection, money supply, capacity utilization, government spending, gross domestic product

\section{Introduction}

The Nigeria economy has been hit hard by recession caused by excessive imports, plunging oil revenue and sharply low investments inflows (Agri, Mailafia, \& Umejiaku, 2017).

The country started moving towards recession in 2013 when the price of crude oil began rolling downwards from US $\$ 118$ per barrel. That process continued throughout 2015, which was the first year since 1995 when average crude price fell down below the bench mark used for the annual budget. Nigeria economy was last in recession, for less than a year in 1991, the National Bureau of Statistics data shows. It also experiences a prolonged recession from 1982-1984. The recent global crisis in the economy has brought the need to shift attention from oil which has created unnecessary shocks to diversify the nation's resource base. Oil alone accounts for 40 per cent of country's GDP, 70 per cent of budget revenue, and 95 per cent of foreign exchange earnings.

In economics a recession is a business cycle contraction, a generally slowdown in economic activities (Meriam-Webster, 2008). A recession has many attributes that can occur simultaneously and includes decline in component measure of economic activity such as corporate investment decisions, government spending, employment level, capacity utilization, business profit, money supply, household income, interest rates, Gross Domestic Income (GDP) and net export activity. All these are macroeconomic indicators which influence negative economic growth. Recession generally occurs when there is a wide spread drop in spending (an adverse demand shock). Government usually reacts to this situation by adopting expansionary macroeconomic policies such as increasing money supply, increasing government spending and decreasing taxation. Economist Koo (2009) wrote that under ideal conditions, a country's economy should have the household sector as net savers and the corporate sector as net borrowers, with the government budget nearly balanced and net exports near zero. When these relationships become imbalanced, recession can develop within the country or create pressure for recession in another country. Policy responses are often designed to drive the economy back towards this ideal state of balance.

In order to diversify the economy through its tax system, the Federal Government inaugurated a committee to 
review National Tax Policy in the country to streamline multiple taxation, Waivers, tax incentives and tax evasion. The fund raised from taxation is intended to be used in financing the provision of goods and services to satisfy the needs of the citizens (Yamane, 2002). Without adequate taxation the government would not be able to provide key infrastructure and improve standard of living. The issue here is that, are these taxes effectively collected and are they enhancing all these macroeconomic indicators which influence negative economic growth?

\subsection{Statement of the Problem}

The bankruptcy of prominent corporation, inadequacy of money supply, the viability of financial institutions, the high rate of unemployment, the decline in capacity utilization, lack of government spending in providing infrastructure, decrease Gross Domestic Product (GDP) have received a lot of attention. These played an important role in increasing the severity of the crisis. Efforts by various government authorities to evolve viable tax system in the country as a panacea for economic growth and development have failed to truly translate to better living conditions for majority of the citizenry, as the economy is still in recession. According to Chinguwo and Blewit (2012) economic recession, financial crisis and climate change problems combined to make life even more difficult for many working people and their families. Although tax revenue is a sustainable way of generating income for government, the irony, however, is that the level of taxation has not been effectively handled to improve this situation as the economy is still in recession and the revenue generation is still poorly across the country.

The issue of expansion is also made difficult in manufacturing industries at the stock exchange and there were massive labour turnover (layoffs) as a result of low capacity utilization and factory closure (Chukwu, et al., 2013). During an economic crisis, many viable businesses are expected to experience harsh financial stress that could cause them to cease their operations and exist the tax system, resulting in permanent revenue losses. The Federal and State budgets cannot be adequately financed due to decline in exports and crude oil prices, consequently resulting to external borrowing and debt financing. These have negative effect on foreign exchange, loss of jobs, low absorptive capacity, decrease government spending, low standard of living, low supply of money, increased tax evasion and avoidance, and low purchasing power caused by recession in the economy. Every tax administrator strives to achieve collection targets and closely monitor outcomes with worsening economic conditions, and tax agencies all over the world are faced with growing compliance risks involving issues such as tax withholding, tax arrears, loss-reporting businesses and the cash economy.

Sustaining effective revenue collection over the medium term will require tax agencies to skillfully address their most fundamental weaknesses (e.g., enforcement programs, poor organizational and staffing arrangements, weak tax payer services and out dated information system). All these constitute the problem of the investigation; hence, this study attempts to address the issues of effective tax collection as a means of solving economic recession problem in Nigeria.

\subsection{Objectives of the Study}

The main objective of the study is to investigate the effectiveness of tax collection during economic recession in Nigeria. The specific objectives are:

i. To establish the effective Tax collection on Gross Domestic Product

ii. To ascertain the effective Tax collection on Government Spending

iii. To establish the extent of Tax on Capacity Utilisation

iv. To determine the effectiveness of Tax collection on Money Supply

\subsection{Research Questions}

i. To what the effective Tax collection affect Gross Domestic Product?

ii. To what the effective Tax collection affect Government Spending?

iii. To what the effective Tax collection affect Capacity Utilisation?

iv. To what the effective Tax collection affect Money Supply?

\subsection{Statement of the Hypotheses}

$\mathrm{Ho}_{1}$ : Tax collection is not effective to have significant effect on GDP.

$\mathrm{Ho}_{2}$ : Tax collection is not effective to have significant effect on Government Spending.

$\mathrm{Ho}_{3}$ : Tax collection is not effective to have significant effect on Capacity Utilisation. 
$\mathrm{Ho}_{4}$ : Tax collection is not effective to have significant effect on Money Supply.

\section{Literature Review}

\subsection{Theoretical Framework}

\subsubsection{General Equilibrium Business Cycle Theory}

Neoclassical business cycle theory also called general equilibrium business cycle theory was introduced to the economic profession in the models of economic fluctuations in Kydland and Presscoott (1980). This framework was distinct from the predominant earlier approaches to economic fluctuations, because it was built on a theoretical framework of explicit optimization problems for the model's economic decision-makers. It includes analyzing fluctuations between consumption and investment, market output. The approach also included procedures for approximating an equilibrium solution, and for choosing parameter values, including those that govern the shock stochastic processes, within a model environment that is consistent with long-run growth observations.

The work looks at fluctuations arising from shocks other than productivity, including monetary shocks, focal policy shocks, trade shocks, taste shocks, financial market imperfections, financial shocks, risk shocks, imperfectly flexible prices and wages. The general equilibrium business cycle models have made considerable progress in understanding of abstract shocks which do not have a precise definition or acknowledge source. A recession is a business cycle contraction which results in a general slowdown in economic activities, stagners growth and development. However, because the focus of this study has been on studying the effects of tax administration on economic recession (shocks) this model will be adopted for this study.

\subsection{Conceptual Framework}

\subsubsection{Effect of Recession on Economy}

According to the National Bureau of Economic Research (2008) recession is a significant decline in economic activity spread across the economy, lasting more than a few months. Economists believe that recessions are caused by inadequate aggregate demand in the economy, and favor the use of expansionary macroeconomic policy during recession. The following might be termed as some of the effects of recession on the economy:

i. Falling Stocks and Slumping Dividends: As declining revenues eventually show up on its quarterly earnings report, the producer's stock price may reduce, and subsequently dividends decline or automatically stop. This might upset shareholders and discourage prospective investors.

ii. Reduced Consumer Access: Manufacturing firms affected by the recession spend fewer funds on marketing and advertising. Consequently, big advertising agencies making millions of naira per year for advertising services will experience a decline in business.

iii. Employee Lay-offs and Benefit Reductions: It is likely business management might cut off employees and more work will be handled by very fewer persons. Thus, causing long hours on a particular task, productivity per employee may increase, wages increased are stopped, fear of further layoffs persists, lack of motivation at work because of fatigue and work becomes harder in the instance of a manufacturing firm, it may be forced to close plants and discontinue poorly performing brands.

iv. Impacts Large Business: As sales revenue and business profits decline, the manufacturer might cut back on employing or hiring new employees. In the process of trying to cut manufacturing costs and improve the bottom line, the manufacturer might stop buying new equipment, reduce expenditure for marketing, reduce research and development and stop rollouts of new products.

v. Cuts to Quality of Goods and Services: In an attempt to attempt to further cut costs to improve its bottom line, the manufacturers might compromise the quality of its product and thus the desirability of its products.

vi. Credit Impairment and Bankruptcy: Account receivable (AR) is also affected by the recession. The manufacturers might experience slow payment, partially payment, late or not at all. This will drastically reduce revenue and in turn affect the manner in which the manufacturers will pay its own bills.

\subsubsection{Types of Recession}

A severe (GDP down by 10\%) or prolonged (three or four years) recession is referred to an economic depression, although some argue that their causes and cures can be different. As informal shorthand, economists sometimes refer to different recession shapes.

A recession is defined as a period of negative economic growth. However, there can be different causes and types of economic contraction. Different types of recession will influence the length, depth and effects of the 
recession. The following are the different shapes of recession:

i. The V-Shaped Recession: Refers to quick recovery after initial recession. In this scenario, an economy falls into a sharp recession but quickly recovers. When the current recession started in the United States, many held out hope that it would be a "V-Shaped" recession. In the US, V-shaped, or short and sharp contractions followed by rapid and sustained recovery occurred 1954 and 1990-1991.

ii. The W-Shaped Recession: Refers to a double dip recession, where economy goes into recession shortly after recovery from first. In a W-Shaped recession, you would experience a sharp downturn which is followed by small, temporary recovery. After the temporary "blip" in growth, the economy turns lower once again before it eventually puts in a full recovery-Shaped or double dip recession occurred in 1949 and 1980-1982 in US.

iii. The U-Shaped Recession: In a U-Shaped recession, the economy takes a much longer period of time to recover (usually in the timeframe of 12-24 months) from a sharp recession. U-Shaped recessions occurred in 1974-1975 in US and Japan, 1997-1998 in Korea, Hong Kong and South East Asia.

iv. The L-Shaped Recession: Refers to a period of stagnant recovery after initial fall in GDP. Even though technically the economy may have positive growth (e.g., $0.5 \%$ ) it still feels like a recession because growth is very slow and unemployment high. In the L-Shaped recession, the economy doesn't begin to recover for an extremely long period of time (7-10 years). The best example of an L-Shaped recession is Japan in the 1990s. Their housing and equity markets plummeted, and the country was thrown into a multi-year depression. They experienced the L-Shaped recession.

The effect of recession in the economy has resulted to collapse of business, low capacity utilization, decline in government spending due to insufficient funds, low GDP, low money supply, Poor tax system, low standard of living and low employment. The Nigeria economy is looking up, signally an end of the recession according to National Bureau of Statistics (2017). However, conditions remain unchanged and difficult for business and citizenry. If these negative effects persist in the economy, the Nigerian economy might be facing the L-Shaped recession which might take longer than necessary to recover from the economic shocks.

\subsubsection{Capacity Utilization}

The capacity utilization rate measures the proportion of potential economic output that is actually realized. Displayed as a percentage, capacity utilization levels give insight into the overall slack that is in the economy or a firm at a given point in time.

There is a common belief that when utilization rises above somewhere between $82 \%$ and $85 \%$, pricing pressure increases resulting to inflation. Capacity utilization tends to fluctuate with business cycle, with firms adjusting production volumes in response to changing demand. Demand declines sharply during recessions, as unemployment rises, wages fall, consumer confidence decreases and business investments slow. Capacity utilization is an important operational metric for business and it's also a key economic indicator when applied to aggregate productive capacity. Federal Government expenditure to GDP and ratio of foreign direct investment on GDP, all these factors impacted negatively on capacity utilization (Banjoko, 2002).

\subsubsection{Government Spending}

Government spending or expenditure refers to the total amount of money that the government spends in a particular period. It also includes all government consumption, investment and transfer payments. The acquisition by government of goods and services for current use, to directly satisfy the individual or collective needs of the community, is classified as government final consumption expenditure. Government spending can be financed by borrowing, taxation or seigniorage. Changes in government spending are a major component of fiscal policy used to stabilize the macroeconomic business. Government spending is part of fiscal policy and is used by the government to prevent the rather more pernicious side effects of the business cycle. If, for example, the economy is experiencing a recessionary gap, the government could help by increasing government spending. This increase in government spending would help the economy grow because that same extra money will increase consumption and investment, thus helping the economy out of recession.

\subsubsection{Money Supply}

In economics, the money supply (or money stock) is the total amount of monetary assets available in an economy at a particular time. It means the total stock of money in circulation. The circulating money involves the currency, printed notes, money in the deposit accounts and in the form of other liquid assets. Valuation and analysis of the money supply help the economist and policy makers to frame the policy or to alter the existing policy of increasing or reducing the supply of money. The valuation is important as it ultimately affects the 
business cycle and thereby affects the economy. The supply of money is determined by the Central Bank through monetary policy.

Increasing the money supply can affect inflation in prices and at the same time as an increase in output. Central Bank must decide whether the benefits of demand-side economic growth outweigh the costs of potential demand-pull inflation. This resultant inflation could cause the currency to depreciate against others, as fewer goods and services can be bought for the same nominal amount of money. This means that the exchange rate is lower, increasing the price of imports and increasing the competitiveness of exports with their associated effects on the economy.

\subsubsection{Gross Domestic Product}

This is the monetary value of all the finished goods and services produced within a country's borders in a specific time period. The size of a nation's overall economy is typically measured by its GDP, which is the value of all final goods and services produced within a country in a given year. Economics recession can also be defined as a negative real Gross Domestic Product (GDP) growth rate for two consecutive quarters regardless of which fiscal year(s) these quarters may actually fall in. The recently released data from the National Bureau of Statistics showed that Gross Domestic Product (GDP) contracted by $-1.30 \%$ in the fourth quarter of 2016. This translated into an estimated growth rate of $-1.51 \%$ for the full year 2016 . These figures reflect the slow-down in the economy for most of 2016 but also show that the recession may have bottomed out because of an improving trend in several key sectors. Also, the reports details significant aspects of economic activities in the first quarter of this year clearly showed that inflationary trends are coming down, while the major fundamentals are increasingly showing positive outlook.

\subsubsection{Tax collection Capacity}

According to Appah (2010) in Nigeria, tax finance accounts for a little less than $46 \%$ of the total revenue of the government. Taxation is a process of levying and collecting by a public authority with proper jurisdiction, of compulsory contributions from person or body of persons to defray cost incurred by the authority in common interest of all (Ochei, 2010). Musgrave (2004) opines that the level of taxation affects the level of public savings and thus the volume of resources available for capital formation. Tax collection should be effective in the sense of ensuring high compliance by tax payers, and efficient in the sense that collection costs are low relative to revenue collected. Taxation is by far the most significant source of revenue for the government (Ojo, 2003). A well designed tax policy exhibits transparency and easy definability increasing efficiency by reducing collection cost. These collection agencies should be able to:

(a). Identify and evaluate the effects of both current tax policies and policies under consideration;

(b). Simplify the current dispensation, maintain a connection between the rule of law and tax administration;

(c). Aware of any law changes and emerging avoidance practices.

Charging high rate of taxation during economic recession by government agencies has discouraged small businesses to continue in business. Both high interest and tax rates have decreased Nigerian aggregate demand.

\subsubsection{Empirical Review}

Chukwu et al., (2013) empirically examined the effect of Economic Recession in Textile manufacturing industries in Nigeria. A sample of 305 staff of Afprint and Enpee were used or the measurement, using questionnaire instrument and analyzed using percentages. The research finding show that the effect of economic recession in manufacturing industries are low capacity utilization and factory closure, horrendous nosedive in stock market prices delisting of share at the stock exchange, fall in commodity price and low foreign direct investment.

Akperan and Awujola (2013) examined the Global Economic Meltdown and the Nigerian Experience: Time series Secondary data were used for the analysis for the period of 1970-2010. The study used investment as the dependent variable and unemployment, interest Rate, Gross Domestic Product, capital market share index, import, export and exchange rate as explanatory variable. The findings suggested the need for the government to embark on welfare economy for the benefit of both the rich and poor to cushion the effect of economic meltdown.

Agri and Umejiaku (2017) investigated the impact of Economic Recession on Macro-economic Stability and Sustainable Development in Nigeria. The study used multiple regression analysis of time series data on selected macroeconomic variable impacted by economic. Equation 1 measures the impact of recession on macroeconomic stability, while equation 2 measures the sustainable development variable. The results show 
negative impact of these variables on economic growth and sustainable development.

Most of the researchers have investigated the relationship between different aspects of recession on economy in Nigeria. This study therefore differs from the previous studies as it tries to investigate the effectiveness of tax collection as a means of solving economic recession in Nigeria.

\section{Research Methodology}

An ex-post facto research design was adopted for this study. This sample was drawn using the purposive sampling method, which is based on availability of data; the sample period is 14 years from 2003-2016. Data for this study was collected from the secondary sources. The data was obtained from the Central Bank of Nigeria (CBN) statistical bulletin, National Bureau of Statistics (NBS) on line publications, statistics from office of Accountant general of the Federation and Federal Inland Revenue Service (FIRS).

\subsection{Model Specification}

Multiple regression analysis was used to analyze the linear relationship between the dependent variable and independent variable. These variables are summarized and analyzed into various components using multiple regression equation.

The model is given as:

$$
\begin{gathered}
G D P=\alpha+\beta(\operatorname{Tax})+e_{\ldots} \\
G-S P E N D=\alpha+\beta(\operatorname{Tax})+e \ldots \\
C A P-U N I T=\alpha+\beta(\operatorname{Tax})+e \ldots \\
M O N-S U P=\alpha+\beta(\operatorname{Tax})+e_{\ldots} .
\end{gathered}
$$

Where, Independent variables: Tax $=$ Taxation. Dependent Variable: GDP $=$ Gross Domestic Product, G $\mathrm{SPEND}=$ Government Spending, CAP - UNIT $=$ Capacity Utilization, MON $-\mathrm{SUP}=$ Money Supply, $\alpha=$ Intercept, $\beta=$ Beta, $\mathrm{e}=$ Error T.

\subsection{Data Presentation and Analysis}

Table 1. Data employed for the study

\begin{tabular}{cccccc}
\hline & TAX \#' Million & GDP & GOV SPEND \#' Million & CAP UTI & MONEY SUP \#' Million \\
\hline 2003 & $24,040,000.00$ & $13,301,558.86$ & $90,000.00$ & 58 & $2,500,000.00$ \\
2004 & $23,230,000.00$ & $17,321,295.24$ & $101,000.00$ & 60 & $2,510,000.00$ \\
2005 & $21,030,000.00$ & $22,269,977.83$ & $140,000.00$ & 59.88 & $2,600,000.00$ \\
2006 & $23,110,000.00$ & $28,662,468.77$ & $98,000.00$ & 60.3 & $2,590,000.00$ \\
2007 & $26,060,000.00$ & $32,995,384.35$ & $105,000.00$ & 60.5 & $4,000,000.00$ \\
2008 & $26,150,000.00$ & $39,157,884.39$ & $104,000.00$ & 54.9 & $5,100,000.00$ \\
2009 & $3,160,000.00$ & $44,285,560.50$ & $104,000.00$ & 53.7 & $9,890,000.00$ \\
2010 & $26,620,000.00$ & $54,612,264.18$ & $107,000.00$ & 50.7 & $11,000,000.00$ \\
2011 & $29,290,000.00$ & $62,980,397.22$ & $106,000.00$ & 48.4 & $14,000,000.00$ \\
2012 & $36,490,000.00$ & $71,713,935.06$ & $104,000.00$ & 48.5 & $14,500,000.00$ \\
2013 & $24,030,000.00$ & $80,092,563.38$ & $103,000.00$ & 55.1 & $15,100,000.00$ \\
2014 & $23,010,000.00$ & $89,043,615.26$ & $102,000.00$ & 58.3 & $15,200,000.00$ \\
2015 & $3,040,000.00$ & $94,144,960.45$ & $78,000.00$ & 60.3 & $19,000,000.00$ \\
2016 & $3,450,000.00$ & $101,489,492.20$ & $70,000.00$ & 50.7 & $20,100,000.00$ \\
\hline
\end{tabular}

Source: CBN Statistical Bulletin (2016). 
Table 2. Hypothesis

\begin{tabular}{|c|c|c|c|}
\hline \multicolumn{4}{|c|}{ Null Hypothesis: CAP UTI has a unit root } \\
\hline \multicolumn{4}{|l|}{ Exogenous: Constant } \\
\hline \multicolumn{4}{|c|}{ Lag Length: 0 (Automatic-based on SIC, maxlag $=2$ ) } \\
\hline \multirow{2}{*}{\multicolumn{2}{|c|}{ Augmented Dickey-Fuller test statistic }} & $\mathrm{t}$-Statistic & Prob. $^{*}$ \\
\hline & & -1.447574 & 0.01526 \\
\hline \multirow[t]{3}{*}{ Test critical values: } & $1 \%$ level & -4.057910 & \\
\hline & $5 \%$ level & -3.119910 & \\
\hline & $10 \%$ level & -2.701103 & \\
\hline
\end{tabular}

Augmented Dickey-Fuller Test Equation

Dependent Variables: D(CAP_UTI, GDP, MONEY SUPPLY, \& GOVERNMENT SPENDING)

Method: Least Squares

Date: 06/28/17 Time: $12: 22$

Sample (adjusted): 20042016

Included observations: 13 after adjustments

\begin{tabular}{ccccc}
\hline Variable & Coefficient & Std. Error & t-Statistic & Prob. \\
CAP_UTI(-1) & -0.357448 & 0.246929 & -1.447574 & 0.1756 \\
C & 19.47147 & 13.88081 & 1.402762 & 0.0083 \\
R-squared & 0.160015 & Mean dependent var & -0.561538 \\
Adjusted R-squared & 0.083653 & S.D. dependent var & 4.053718 \\
S.E. of regression & 3.880464 & Akaike info criterion & 5.690425 \\
Sum squared resid & 165.6380 & Schwarz criterion & 5.777340 \\
Log likelihood & -34.98776 & Hannan-Quinn criter. & 5.672560 \\
F-statistic & 2.095469 & Durbin-Watson stat & 1.721921 \\
Prob(F-statistic) & 0.015630 & & \\
\hline
\end{tabular}

Source: E-VIEW Output.

*MacKinnon (1996) one-sided p-values.

Augmented Dickey-Fuller test equation revealed the stationary of the data employed. It explains how adequate is the data, sample size (observation) and the model fitness. The Durbin-Watson (DW) test assumed that there is no autocorrelation between variable if the DW value is higher than 1.5. The result revealed that DW of 1.72 implies that there is no autocorrelation between the variables. The results of the unit root tests are presented in Table 1 . The result showed that all the variables are stationary at level, and also stationary at first difference.

\subsection{Hypotheses Testing}

3.3.1 Hypothesis One

$\mathrm{Ho}_{1}$ : Tax does not have significant effect on GDP

Table 3. Model summary ${ }^{\mathrm{b}}$

\begin{tabular}{cccccc}
\hline Model & $\mathrm{R}$ & $\mathrm{R}$ Square & Adjusted R Square & Std. Error of the Estimate & Durbin-Watson \\
\hline 1 & $.332^{\mathrm{a}}$ & .110 & .036 & 29300362.49032 & .219 \\
\hline
\end{tabular}

${ }^{\mathrm{a}}$ Predictors: (Constant), Tax. ${ }^{\mathrm{b}}$ Dependent Variable: GDP. 
Table 4. Coefficients ${ }^{\mathrm{a}}$

\begin{tabular}{lcccccc}
\hline \multirow{2}{*}{ Model } & \multicolumn{2}{c}{ Unstandardized Coefficients } & Standardized Coefficients & \multirow{2}{*}{ t } & \multirow{2}{*}{ Sig. } \\
\cline { 2 - 4 } & B & Std. Error & Beta & & \\
\hline 1 & (Constant) & 73856728.046 & 18293767.506 & & 4.037 & .002 \\
& Tax & -.963 & .791 & -.332 & -1.218 & .247 \\
\hline
\end{tabular}

${ }^{\mathrm{a} D e p e n d e n t ~ V a r i a b l e: ~ G D P . ~}$

Co-efficient of correlation denoted by " $\mathrm{R}$ " explains the relationship between variable. As shown in the model summary, the relationship between Tax and GDP is about 33\%. R-Square being the determinant of correlation explains the extent to which the independent variable could explain the dependent variable. $\mathrm{R}$ square as shown in model summary is about $11 \%$, which implies that the independent variables cannot predict or determine dependent variables beyond $11 \%$. This simply means that only $11 \%$ of GDP can be explained by tax.

This study revealed that a unit change in tax account for about $-.96 \%$ unit change in GDP. This study revealed that reported taxes by tax administrator do not significantly affect Gross Domestic Product.

Decision: The $p$ value of 0.247 is higher than 0.05 , we hereby conclude that reported taxes by tax administrators do not have significant effect on GDP, and hereby accept null hypothesis.

3.3.2 Hypothesis Two

$\mathrm{Ho}_{2}$ : Tax does not have significant effect on Government Spending

Table 5. Model summary ${ }^{\mathrm{b}}$

\begin{tabular}{cccccc}
\hline Model & $\mathrm{R}$ & $\mathrm{R}$ Square & Adjusted R Square & Std. Error of the Estimate & Durbin-Watson \\
\hline 1 & $.488^{\mathrm{a}}$ & .238 & .174 & 14366.26091 & 1.818
\end{tabular}

${ }^{\mathrm{a}}$ Predictors: (Constant), Tax. ${ }^{\mathrm{b}}$ Dependent Variable: GOV SPENDING.

Table 6. Coefficients ${ }^{\mathrm{a}}$

\begin{tabular}{ccccccc}
\hline \multirow{2}{*}{ Model } & \multicolumn{2}{c}{ Unstandardized Coefficients } & Standardized Coefficients & \multirow{2}{*}{$\mathrm{T}$} & \multirow{2}{*}{ Sig. } \\
\cline { 3 - 4 } & & $\mathrm{B}$ & Std. Error & Beta & & \\
\hline \multirow{2}{*}{1} & (Constant) & 85168.709 & 8969.617 & & 9.495 & .000 \\
& $\operatorname{Tax}$ & .210 & .000 & .488 & 1.935 & .077 \\
\hline
\end{tabular}

${ }^{\mathrm{a} D e p e n d e n t ~ V a r i a b l e: ~ G O V ~ S P E N D I N G . ~}$

The relationship between Tax and government spending is about $49 \%$. R-Square being the determinant of correlation explains the extent to which the independent variable could explain the dependent variable. $\mathrm{R}$ square as shown in model summary is about $24 \%$. This implies that taxes account can explain government spending up to $24 \%$. This study revealed that a unit change in tax account for about $21 \%$ unit change in GDP.

Decision: The $p$ value of 0.77 is higher than 0.05 , we hereby conclude that reported taxes by tax administrators do not have significant effect on government spending, and hereby accept null hypothesis.

\subsubsection{Hypothesis Three}

$\mathrm{Ho}_{3}$ : Tax does not have significant effect on Capacity Utilisation

Table7. Model summary ${ }^{\mathrm{b}}$

\begin{tabular}{lccccc}
\hline Model & $\mathrm{R}$ & $\mathrm{R}$ Square & Adjusted R Square & Std. Error of the Estimate & Durbin-Watson \\
\hline 1 & $.179^{\mathrm{a}}$ & .032 & -.049 & 4.69723 & .694 \\
\hline
\end{tabular}

${ }^{\mathrm{a}}$ Predictors: (Constant), Tax. ${ }^{\mathrm{b}}$ Dependent Variable: CAP UTILISATION. 
Table 8. Coefficients ${ }^{\mathrm{a}}$

\begin{tabular}{|c|c|c|c|c|c|}
\hline \multirow{2}{*}{ Model } & \multicolumn{2}{|c|}{ Unstandardized Coefficients } & \multirow{2}{*}{$\frac{\text { Standardized Coefficients }}{\text { Beta }}$} & \multirow{2}{*}{$\mathrm{t}$} & \multirow{2}{*}{ Sig. } \\
\hline & B & Std. Error & & & \\
\hline \multirow[t]{2}{*}{ (Constant) } & 57.329 & 2.933 & & 19.548 & .000 \\
\hline & $-7.967 \mathrm{E}-8$ & .000 & -.179 & -.629 & .541 \\
\hline
\end{tabular}

${ }^{\mathrm{a}}$ Dependent Variable: CAP UTILISATION.

The relationship between Tax and capacity utilisation is about $18 \%$. R-Square being the determinant of correlation explains the extent to which the independent variable could explain the dependent variable. $\mathrm{R}$ square as shown in model summary is about $3 \%$. This implies that taxes account taxes can explain capacity utilisation up to $3 \%$. This study revealed that a unit change in tax account for about $-7.96 \%$ unit changes in capacity utilisation.

Decision: The $p$ value of 0.541 is higher than 0.05 , we hereby conclude that reported taxes by tax administrators do not have significant effect on capacity utilisation, and hereby accept null hypothesis.

\subsubsection{Hypothesis Four}

$\mathrm{Ho}_{4}$ : Tax does not have significant effect on Money Supply

Table 9. Model summary ${ }^{\mathrm{b}}$

\begin{tabular}{lccccc}
\hline Model & R & R Square & Adjusted R Square & Std. Error of the Estimate & Durbin-Watson \\
\hline 1 & $.359^{\mathrm{a}}$ & .129 & .057 & 6347092.78976 & .151 \\
\hline
\end{tabular}

${ }^{\mathrm{a}}$ Predictors: (Constant), Tax. ${ }^{\mathrm{b}}$ Dependent Variable: MONEY SUPPLY.

Table 10. Coefficients ${ }^{\mathrm{a}}$

\begin{tabular}{ccccccc}
\hline \multirow{2}{*}{ Model } & \multicolumn{2}{c}{ Unstandardized Coefficients } & \multicolumn{2}{c}{ Standardized Coefficients } & \multirow{2}{*}{ t } & \multirow{2}{*}{ Sig. } \\
\cline { 3 - 5 } & & $\mathrm{B}$ & Std. Error & Beta & & \\
\hline \multirow{2}{*}{1} & (Constant) & 14640237.496 & 3962826.053 & & 3.694 & .003 \\
& Tax & -.228 & .171 & -.359 & -1.334 & .207 \\
\hline
\end{tabular}

a. Dependent Variable: MONEY SUPPLY.

The relationship between Tax and money supply is about $36 \%$. R-Square being the determinant of correlation explains the extent to which the independent variable could explain the dependent variable. R square as shown in model summary is about $13 \%$. This implies that taxes account taxes can explain money supply up to $13 \%$. This study revealed that a unit change in tax account for about $-.23 \%$ unit change in money supply.

Decision: The $\mathrm{p}$ value of 0.207 is higher than 0.05 , we hereby conclude that reported taxes by tax administrators do not have significant effect on money supply, and hereby accept null hypothesis.

\section{Conclusion}

Economic recession has eaten deep into the economy to the extent that taxes generated cannot serve as a pivot upon which the economy could strive. In line with the study conducted by Agri and Umejiaku (2017), they investigated into the impact of Economic Recession on Macro-Economic Stability and Sustainable Development in Nigeria. The results show macroeconomic indexes have negative impact on economic growth and sustainable development. Capacity utilisation, Government spending, and GDP among other macroeconomic index are badly affected by the current economic recession and it is quit unfortunate that one of the needed panacea (tax) is poorly collected.

\section{Recommendation}

This research is hereby recommending that the government of Nigeria should encourage the proper tax collection and optimally its deployment (usage). Tax should be considered as the urgent and needful panacea to rescue the 
current economic illness that Nigeria is facing. This should be done by ensuring that relevant tax authorities have good tax collection system like effective tax data base, effective E- tax registration, effective E-tax payment and all tax payers should have tax identification number.

\section{References}

Agri, E. M., Mailafia, D., \& Umejiaku, R. J. (2016). Impact of Economic Recession on Macroeconomic stability and sustainable Development in Nigeria. Science journal of Economics.

Akpa, A. (2011). Knowledge Creation Process: Concept and Application in Social Research. Makurdi: Aboki Publishers.

Akperan, J. A., \& Awujola, A. (2013). Global Economic Meltdown and the Nigerian Experience: An Enpirical Analysis. Journal of Economics and sustainable Development, 4(19).

Anyanwu, J. C. (1993). Monetary Economic: Theory, Policy and Institution. Onitsha: Hybrid Publishers.

Appah, E. (2010). The Problem of Tax Planning and Administration in Nigeria: The Federal and State Predicament. Onitsha: Hybrid Publishers.

Banjoko, S. A. (2010). Productivity in the Nigerian Manufacturing Sub-Sector: An Error Correction Model. Journal of Economic, Finance and Administration Sciences, 20, 1450-2275.

Chinguwo, P., \& Blewit, J. (2012). The Global Financial Crisis, Working People and Sustainable Level. A Schumacher Institute Challenge Paper. https://doi.org/10.19026/ajbm.7.2106

Chukwu, B. A., Liman, N. A., Enudu, T. O., \& Eliaghe, A. F. (2015). The Effect of Economic Recession in Textile Manufacturing industries in Nigeria. Asian Journal of Business management, 7(3), 43-54.

Das-Gupta, A., Estrada, G. B., \& Park, D. (2016). Measuring Tax Administration Effectiveness and its Impact on Tax Revenue. ERIA Discussion paper series

Koo, R, C. (2009). The Holy Grail of Microeconomic lessons from Japans Great Recession. John Wiley and Sons Asia Pte Ltd.

Kydland, F. E., \& Prescott, E. C. (1980). A Competitive theory of Fluctuations and Feasibility and Desirability of Stabilization Policy. National Bureau of Economic Research, 168-198.

Meriam-Webster. (2008). Meriam-Webster on live dictionary. Retrieved from http://www.Merrianm-Webster.com/dictionary/recession

Musgrave, R. A. (2004). Public Finance in Theory and Practice. New Delhi, India: Tata McGraw Hill.

National Bureau of Economic Research (NBER). (2003). Text of the NBERS statement for Recession. Retrieved May 12, 2017, from http://www.USA today.com/money

Ochei, O. O. (2010). Nigerian Tax Reform: Challenges and Prospects. Retrieved May 15, 2017, from http://www.org/others/nigeria-tax reforms

Ojo, S. (2003). Fundamental Principles of Nigerian Tax, Sagribra Tax Publications. Lagos Nigeria.

Tosun, U. N., \& Abiza, D. (2005). Appraising Nigeria's Tax Efforts: A Comparative Econometric Analysis. Journal of Economic and Financial Review, Central Bank of Nigeria, 46(1), 620. Retrieved from $\mathrm{http}: / / \mathrm{www}$.nationonilne/nigeria-economic recession

Yamane, T. (2002). An Introductory Analysis. New York: Harper and Row Publishers.

\section{Copyrights}

Copyright for this article is retained by the author(s), with first publication rights granted to the journal.

This is an open-access article distributed under the terms and conditions of the Creative Commons Attribution license (http://creativecommons.org/licenses/by/4.0/). 